\title{
Géolinguistique
}

14 | 2013

Varia

\section{Standard Dutch with a Regional Accent}

A Study of the Influence of Regional Background on the Evaluation of Regional Accents

Néerlandais standard avec un accent régional :étude de l'influence du contexte régional sur l'évaluation des accents régionaux

\section{Hans Van de Velde and Anne-France Pinget}

\section{OpenEdition}

\section{Journals}

\section{Electronic version}

URL: http://journals.openedition.org/geolinguistique/957

DOI: 10.4000/geolinguistique.957

ISSN: 2650-8176

\section{Publisher}

UGA Éditions/Université Grenoble Alpes

\section{Printed version}

Date of publication: 15 December 2013

Number of pages: 171-186

ISBN: 978-2-84310-264-6

ISSN: 0761-9081

\section{Electronic reference}

Hans Van de Velde and Anne-France Pinget, « Standard Dutch with a Regional Accent »,

Géolinguistique [Online], 14 | 2013, Online since 30 April 2019, connection on 01 November 2020. URL: http://journals.openedition.org/geolinguistique/957; DOI : https://doi.org/10.4000/geolinguistique. 957 


\title{
Standard Dutch with a regional accent
}

\section{A study of the influence of regional background on the evaluation of regional accents}

\author{
Hans Van de Velde et Anne-France Pinget \\ Utrecht Institute of Linguistics OTS, Utrecht University
}

\begin{abstract}
This paper reports on an evaluation study of standard Dutch as spoken in four regions in The Netherlands by listeners from the same regions. 429 listeners rated 20 listeners on four Likert scales (standard, regional, beautiful and polished). It is shown that the regional accents are rated differently, and the Randstad accent receives the highest scores for accent norm and accent euphony, while the peripheral regions get the lowest scores. The evaluation is rather homogenous all over The Netherlands, but one region has a deviant pattern. Listeners from the South are more positive about their own Southern accent and less positive about the prestigious Randstad one. In addition, a simulation study was conducted to detect how many speakers per region are needed to get valid results in an evaluation task. It is shown that at least three speakers per region are needed to capture the complex interactions between the region of the speaker and the region of the listener.
\end{abstract}

\section{Keywords}

Dutch, standardization, regional accent, evaluation, research methods.

\section{Résumé}

Cet article présente les résultats d'une étude d'évaluation du néerlandais standard normé parlé dans quatre régions des Pays-Bas et évalué par des 
locuteurs de ces mêmes régions. 429 participants ont évalué 20 locuteurs sur quatre échelles de Likert (standard, régional, beau et soigné). Les résultats montrent des différences dans l'évaluation des différents accents régionaux, et indiquent que les participants attribuent les meilleurs scores à l'accent de Randstad du point de vue du respect de la norme et de l'euphonie, tandis que les accents des régions périphériques obtiennent les scores les plus faibles. L'évaluation des accents est plutôt homogène sur tout le territoire des Pays-Bas, cependant une des régions présente des caractéristiques différentes. En effet, les évaluateurs du sud des Pays-Bas se montrent plus positifs envers leur propre accent et moins positifs envers l'accent normalement considéré comme prestigieux de la région Randstad. En outre, une simulation informatique a été effectuée pour déterminer le nombre de locuteurs par région nécessaire pour obtenir des résultats valides dans ce type d'étude évaluative. Les résultats de la simulation indiquent qu'au moins trois locuteurs sont nécessaires pour représenter chaque région si l'on veut révéler les interactions complexes entre la région d'origine du locuteur et la région d'origine de l'évaluateur.

\section{Mots-clés}

Néerlandais, standardisation, accent régional, évaluation, méthodologie.

\section{Introduction}

This paper reports on a quantitative study of the evaluation of four regional accents of standard Dutch as spoken in The Netherlands by listeners from these regions. Our study has a three-fold aim. First, we want to show that there are regional accent differences in standard Dutch as spoken in The Netherlands. Second, we test whether the evaluation of these regional accents differs across regions. Third, there is a methodological aim: how many speakers are needed for each accent to get stable evaluations of the regional differences? In Section 2 we focus on the standard language myth and show that speaking without an accent is an early 20th century ideal that has never been reached in the standardization process of Dutch. In Section 3 the design of our evaluation study is sketched. For each of the four regions in the design, speech samples of five young male teachers of Dutch were selected. Data come from a sociolinguistic interview intended to elicit standard Dutch. The results of our evaluation study are presented in Section 4. In order to answer the third research question, a simulation study with smaller speaker sets is presented in Section 5. The conclusions are formulated in Section 6. 


\section{The standard language myth: speaking without an accent}

The Dutch linguist Van Haeringen (1924, p. 65), inspired by Otto Jespersen's ideas, formulated his vision on the standard language: in standard pronunciation a speaker's regional origin cannot be detected. He observed that in the 1920's this ideal had not been reached yet, but that it will be the inevitable end point of the standardization of Dutch in The Netherlands. Van Haeringen (1951) had to admit that 25 years later this accentless uniformity was still a dream, not a reality.

More than 80 years after Van Haeringen, Smakman (2006) reports on a number of studies of the characteristics of standard Dutch. In a written questionnaire $30 \%$ of his respondents define - in an open question - standard Dutch as 'non-regional', which is with 'correct' the most frequent answer. However, in a telephone survey in two communities in the Randstad area (the economic and cultural center of The Netherlands) and two in the South, $60 \%$ of his respondents give an affirmative answer to the question whether regional characteristics can be detected in standard Dutch speech, while one quarter of his respondents deny the presence of regional characteristics.

It seems that Van Haeringen's dream is still alive among Dutch language users, but in practice it has never been reached. In the 1990's it was not only observed that in The Netherlands standard pronunciation showed considerable variation and was changing rapidly (Van de Velde, Van Hout \& Gerritsen, 1997), but also that more and more highly educated speakers of standard Dutch spoke the standard variety with an obvious regional accent. These observations were the basis for a study of variation and change in contemporary standard Dutch as spoken in The Netherlands and Flanders (Van Hout et al., 1999; Van de Velde et al., 2010). All speakers were teachers of the Dutch language at high schools, who are generally considered as competent speakers of the standard variety (Van de Velde \& Houtermans, 1999; Smakman, 2006), but their speech is expected to show regional traces (see also Grondelaers, Van Hout \& Steegs, 2010). Systematic regional differences showed up in the pronunciation of vowels (Adank, Van Hout \& Van de Velde, 2007; Van der Harst, 2011; Van der Harst, Van de Velde \& Van Hout, to appear), consonants (Verstraeten \& Van de Velde, 2001; Kissine, Van de Velde \& Van Hout, 2003; Van der Harst, Van de Velde \& Schouten, 2007) and loan words (Van de Velde \& Van Hout, 2002). In this paper we will study how native speakers of Netherlandic Dutch from different regions evaluate these regional differences in standard Dutch pronunciation. 


\section{Method}

In this section the design of our study of regional variation in accent evaluation of Netherlandic standard Dutch is sketched. In Section 3.1 the speakers are introduced. The speech stimuli for the experiments on spoken and read standard Dutch are described in Section 3.2. The selection and characteristics of the Dutch listeners participating in this study are presented in Section 3.3. The evaluation scales are introduced in Section 3.4. The procedure of data collection is described in Section 3.5.

\subsection{Speakers}

Speakers are selected from the VTD corpus compiled for the study of variation and change in standard Dutch pronunciation in The Netherlands and Flanders at the turn of the millennium (see Van de Velde et al., 2010). For this research, we only selected speakers from four regions in The Netherlands. For each region we selected five young $(m e a n=36)$ male speakers for the listening experiments. There are no age differences between the regions (oneway: $\mathrm{F}=.340 ; \mathrm{df}_{1}=3 ; \mathrm{df}_{2}=16 ; \mathrm{p}=.797$ ). The speakers are all teachers of the Dutch language at high schools in middle-sized provincial towns and grew up and live in that region. They are all highly educated native speakers of Dutch, who speak standard Dutch on a daily basis and who are generally considered competent speakers of the standard variety (Van de Velde \& Houtermans, 1999; Smakman, 2006), but their speech is expected to show regional traces (see also Grondelaers et al., 2010), which is confirmed by the studies listed in Section 2. The speakers knew they participated in a study of standard Dutch pronunciation. A young male speaker of standard Dutch interviewed them in a quiet room at the speaker's home or school.

For the selection of regions and speakers we followed socio-geographic and dialectological criteria. Randstad is the central zone, the cultural and economic heart of The Netherlands, which also has a strong influence on present-day developments in standard Dutch. The selected speakers from Randstad teach at schools in Gouda and Alphen aan den Rijn. The selected cities in each region are marked with a dot in Figure 1. We also selected two peripheral zones that are geographically maximally distant from the central zone and each other. The dialects spoken in the peripheral regions are phonetically maximally distant from those of the central region (Hoppenbrouwers \& Hoppenbrouwers, 2001). These zones are North (selected cities: Assen, Veendam and Winschoten) and South (selected cities: Geleen, Roermond and Sittard). Finally, a geographically and linguistically intermediate zone was selected, meaning that the region is closer to the central region than the peripheral regions and that its dialects are 
closer to the standard language. The selected cities in Middle are Culemborg, Tiel and Veenendaal.

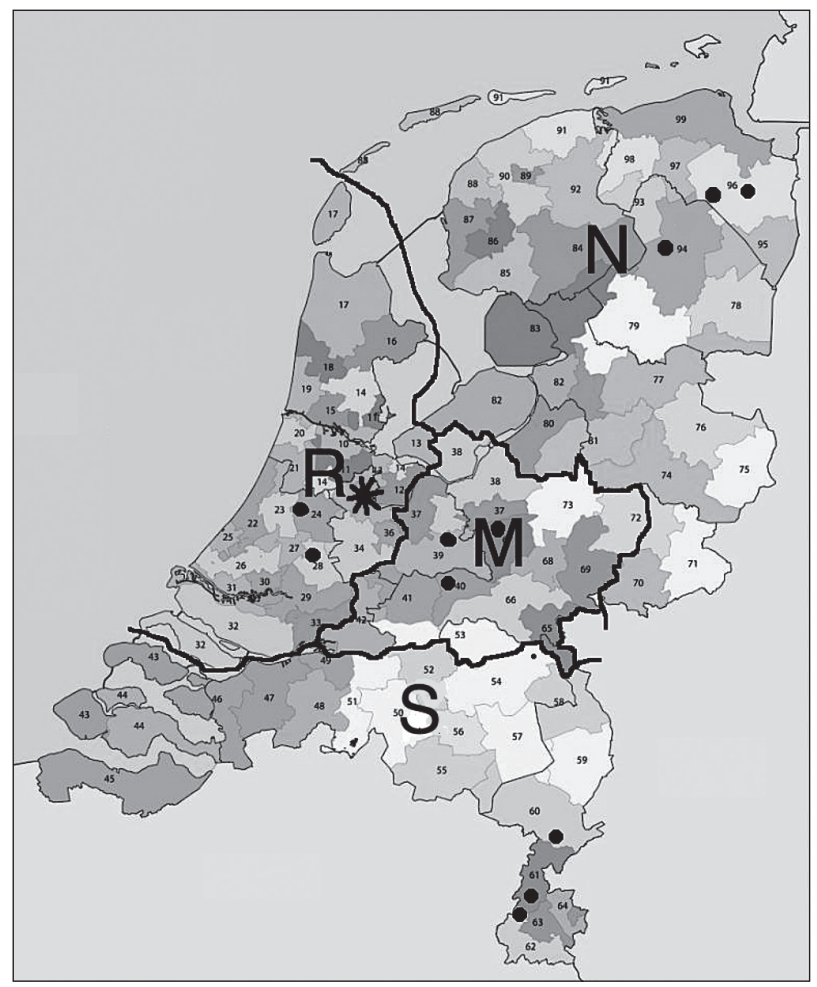

Figure 1. - Geographical origin of speakers and listeners.

Four regions are distinguished: $\mathrm{R}=\mathrm{Randstad}, \mathrm{M}=$ Middle, $\mathrm{N}=$ North, $\mathrm{S}=$ South . The numbers refer to the first two digits of the zip codes. The regional origin of the speakers is marked with dots. Utrecht is marked with an asterisk.

Adapted version of a map on $<w w w$.allesoverpostcodes.nl>.

\subsection{Stimuli}

Two types of stimuli-reading style and spontaneous speech - are used in this research, in separate experiments. The speech fragments were selected from two parts of the interview. For reading style, four sentences were selected for each speaker out of a fixed set of five sentences. None of the selected sentences contained speech errors, hesitations or disturbing background noise. For spontaneous speech, fragments of about 20 seconds were selected from a conversation between the researcher and the teachers of Dutch during the final part of the interview. The speech fragments did 
not contain references to age, social class or regional background of the speaker, nor speech errors, hesitations or disturbing background noise.

Style is a factor in our research design and will be integrated in the statistical analyses. However, a discussion of the differences between spontaneous speech and reading style is outside the scope of this paper and discussed in detail in Pinget, Rotteveel \& Van de Velde (to appear).

\subsection{Listeners}

The analyses are based on 204 listeners for the spontaneous speech stimuli and 225 listeners for the reading style stimuli. There were more participants, but those who did not provide all personal information, did not complete the experiment or did the experiment in an amount of time that did not allow listening to the fragments were removed from the database. Also participants who were not native speakers of Dutch or lived outside The Netherlands were excluded. Due to a strong bias of our sample towards highly educated listeners, we decided to exclude participants with a low educational level. Consequently, it is to be expected that our listener group in comparison with those with a lower educational profile will attribute more positive values to non-regional accented speech (Kraaykamp, 2005). Listeners were classified in one of the four regions (see Section 3.1) on the basis of their answer on the question where did you live most of your life? (see Section 3.1 and Figure 1). Table 1 gives an overview of the distribution of the listeners over the regions, split up by speech style of the stimuli. The differences in regional distribution over experiments is not significant $\left(\mathrm{chi}^{2}=3.548 ; \mathrm{df}=3 ; \mathrm{p}=.315\right)$, but there are clearly more participants from the Randstad area. This is not surprising as this area has the highest population numbers and Utrecht-marked with an asterisk in Figure 1 and out starting point for data collection (see Section 3.5) - is situated in this area. There is no significant age difference of the listeners between the two experiments (oneway: $\mathrm{F}=.056 ; \mathrm{df}_{1}=1 ; \mathrm{df}_{2}=427 ; \mathrm{p}=.813$ ). Only the malefemale listeners distribution is significantly different $\left(\mathrm{chi}^{2}=7.664 ; \mathrm{df}=1\right.$; $\mathrm{p}=.006)$ between spontaneous speech $(\mathrm{m}=80 ; \mathrm{f}=124)$ and reading style $(\mathrm{m}=60 ; \mathrm{f}=165)$ stimuli.

\begin{tabular}{lcccccccccc}
\hline & \multicolumn{2}{c}{ Randstad } & \multicolumn{2}{c}{ Middle } & \multicolumn{2}{c}{ North } & \multicolumn{2}{c}{ South } & \multicolumn{2}{c}{ Total } \\
\hline & $\mathrm{n}$ & $\%$ & $\mathrm{n}$ & $\%$ & $\mathrm{n}$ & $\%$ & $\mathrm{n}$ & $\%$ & $\mathrm{n}$ & $\%$ \\
\hline spontaneous speech & 72 & 35.3 & 39 & 19.1 & 40 & 19.6 & 53 & 26.0 & 204 & 100 \\
reading style & 93 & 41.3 & 49 & 21.8 & 33 & 14.7 & 50 & 22.2 & 225 & 100 \\
\hline
\end{tabular}

Table 1. - Regional background of the listeners, split up by speech style of the stimuli $(n=429)$. 


\subsection{Evaluation scales}

Each speech fragment was evaluated using 7-point Likert scales running from completely disagree to completely agree. We opted for direct measurements of the characteristics of the speech as it is expected that highly educated listeners are able to deal with explicit normative judgements. Furthermore, it enables us to test a larger number of stimuli in a short amount of time. On the basis of previous research on standard Dutch pronunciation (e.g. Smakman, 2006) and as our primary interest is in the standardness of regionally accented speech, we selected four scales, embedded in the statements "this speech sounds ...": standard, regional, beautiful and polished. The latter three scales showed strong correlations (between .62 and .93) with the scale standard in Smakman's study of Dutch broadcasters. Grondelaers et al. (2010) consider standard and regional as scales of accent norm, beautiful and polished as scales of accent euphony. The scale regional was recoded to non-regional in the analyses, so that all 'positive' evaluations have a high score ( 1 being the minimum and 7 the maximum).

\subsection{Procedure}

Data was collected by means of an Internet application. The same procedure was followed for both types of stimuli. Each experiment consisted of four parts: 1) questions on listener background; 2) instructions and two sample stimuli to get familiar to the evaluation task; 3) evaluation task with the twenty stimuli in a random order; 4) classification task with the twenty stimuli in a random order. The results of the classification task will not be discussed in this paper, but can be found in Pinget et al. (to appear). First year students of undergraduate courses in linguistics at Utrecht University were invited to participate in one of the experiments and asked to distribute the hyperlink and an invitation to participate through their social network. As mentioned in Section 3.3, this approach resulted in a bias towards participants with a high level of education.

\section{Results}

The reliabilities of the scales in both experiments range between .705 and .849 (see Table 2), which is high enough for further statistical analysis. In both speech styles, the correlations between the scales are all significant $(\mathrm{p}<.05)$. The highest correlations can be found between the accent norm scales standard and not-regional $(r=.64$ in spontaneous speech and $\mathrm{r}=.60$ in reading style) and between the accent euphony scales beautiful 
and polished ( $\mathrm{r}=.60$ in both styles). It should be noted that the correlations are much lower than in Smakman's (2006) research on Dutch, but he calculated correlations over mean scores of listeners, not on the separate ratings of the listeners. Due to the weak to moderate correlations between the scales, we decided to analyse them separately.

\begin{tabular}{lllll|lllll}
\hline \multicolumn{3}{l|}{ Spontaneous speech } & & \multicolumn{4}{l}{ Reading style } \\
\hline standard & beautiful & not-regional & polished & standard & beautiful & not-regional & polished \\
\hline$\alpha=.795$ & $\alpha=.766$ & $\alpha=.759$ & $\alpha=.808$ & $\alpha=.849$ & $\alpha=.820$ & $\alpha=.705$ & $\alpha=.848$ \\
\hline standard & .46 & .64 & .48 & standard & .58 & .60 & .47 \\
& beautiful & .29 & .63 & & beautiful & .36 & .63 \\
& & not-regional & .32 & & & not-regional & .30 \\
\hline
\end{tabular}

Table 2. - Reliabilities correlations between the scales, split up by style.

Given are Cronbach's alpha and Pearson correlations. All correlations are significant $(\mathrm{p}<.05)$.

\begin{tabular}{|c|c|c|c|c|c|c|c|c|}
\hline \multirow[t]{2}{*}{ Effects } & \multicolumn{4}{|c|}{ Standard } & \multicolumn{4}{|c|}{ Not-regional } \\
\hline & $\mathrm{df}_{1}$ & $\mathrm{df}_{2}$ & $\mathrm{~F}$ & $\mathrm{p}$ & $\mathrm{df}_{1}$ & $\mathrm{df}_{2}$ & $\mathrm{~F}$ & $\mathrm{p}$ \\
\hline Lregion & 3 & 428.065 & 1.200 & .309 & 3 & 428.056 & 3.607 & .013 \\
\hline Type & 1 & 428.065 & 3.778 & .053 & 1 & 428.056 & 9.249 & .003 \\
\hline Sregion & 3 & 44.403 & 67.294 & .000 & 3 & 41.829 & 72.746 & .000 \\
\hline Lregion * Type & 3 & 428.065 & 0.701 & .552 & 3 & 428.056 & 0.651 & .583 \\
\hline Lregion * Sregion & 9 & 7772.897 & 5.296 & .000 & 9 & 7651.401 & 4.901 & .000 \\
\hline Type $*$ Sregion & 3 & 588.086 & 13.678 & .000 & 3 & 418.895 & 9.693 & .000 \\
\hline \multirow[t]{3}{*}{ Lregion $*$ Type $*$ Sregion } & 9 & 8133.765 & 1.450 & .161 & 9 & 8133.128 & 0.880 & .542 \\
\hline & \multicolumn{4}{|c|}{ Beautiful } & \multicolumn{4}{|c|}{ Polished } \\
\hline & $\mathrm{df}_{1}$ & $\mathrm{df}_{2}$ & $\mathrm{~F}$ & $\mathrm{p}$ & $\mathrm{df}_{1}$ & $\mathrm{df}_{2}$ & $\mathrm{~F}$ & $\mathrm{p}$ \\
\hline Lregion & 3 & 428.264 & 0.732 & .534 & 3 & 428.221 & 1.460 & .225 \\
\hline Type & 1 & 428.264 & 0.561 & .454 & 1 & 428.221 & 34.526 & .000 \\
\hline Sregion & 3 & 39.476 & 51.985 & .000 & 3 & 31.442 & 51.912 & .000 \\
\hline Lregion * Type & 3 & 428.264 & 0.221 & .882 & 3 & 428.221 & 0.206 & .892 \\
\hline Lregion * Sregion & 9 & 7321.439 & 7.753 & .000 & 9 & 7105.764 & 1.835 & .057 \\
\hline Type $*$ Sregion & 3 & 105.042 & 6.684 & .000 & 3 & 101.900 & 8.318 & .000 \\
\hline Lregion * Type * Sregion & 9 & 8135.229 & 3.542 & .000 & 9 & 8130.101 & 2.480 & .008 \\
\hline
\end{tabular}

Table 3. - Results of the mixed models linear regressions for the four scales.

Speaker and listener are random factors in the analysis, the fixed factors are type, region of the listener (Lregion) and region of the speaker (Sregion). Given are the degrees of freedom, F-ratio and p-value. The effects that are the focus of this paper are printed in bold. 
For each scale a mixed model linear regression analysis was conducted with speaker and listener as random factors and region of the listener, region of the speaker and type as fixed factors. The results are presented in Table 3. Given our research aims, we will focus in this paper on the main effects of listener region and speaker region and their interaction (printed in bold in Table 3). An interpretation of the type effects can be found in Pinget et al. (to appear), but they are not crucial for answering the research questions of this paper. The mean scores for the scales, split up by region speaker and region listener are given in Table 4 and visualized in Figure 2.

For standard, not-regional and beautiful, there is a significant main effect $(\mathrm{p}<.05)$ of the region of the speaker, and for polished it approaches significance $(\mathrm{p}=.057)$. And for all scales, the interaction between region of the speaker and region of the listener are significant. For region of the listener there is only a significant effect for the scale not-regional $(\mathrm{p}=.013)$. What does this mean? First, it shows that there are regional accents of standard Dutch, as there are systematic differences in their evaluation by Netherlandic native speakers of Dutch. Second, the highly educated listeners in The Netherlands seem to share to a large extent the same accent norms, but there are subtle differences between the regions-mainly in interaction with the accent of the speakers - which contradicts the results of Grondelaers et al. (2010), who claim on the basis of similar research that there is a completely uniform norm, shared by listeners from all regions. We will look into more detail in the observed differences.

\begin{tabular}{|c|c|c|c|c|c|c|c|c|c|c|c|}
\hline & & \multicolumn{10}{|c|}{ Listeners } \\
\hline & & $\mathrm{R}$ & $\mathrm{M}$ & $\mathrm{N}$ & $\mathrm{S}$ & Sregion & $\mathrm{R}$ & $\mathrm{M}$ & $\mathrm{N}$ & $\mathrm{S}$ & Sregion \\
\hline & & \multicolumn{5}{|c|}{ Standard } & \multicolumn{5}{|c|}{ Not-regional } \\
\hline \multirow{6}{*}{\multicolumn{2}{|c|}{ Speakers R }} & 5.18 & 5.01 & 5.10 & 4.80 & 5.02 & 5.06 & 5.18 & 5.20 & 4.58 & 5.00 \\
\hline & & 4.30 & 4.27 & 4.25 & 4.16 & 4.24 & 3.83 & 3.99 & 3.92 & 3.70 & 3.86 \\
\hline & & 3.49 & 3.43 & 3.39 & 3.45 & 3.44 & 3.30 & 3.34 & 3.22 & 3.23 & 3.27 \\
\hline & & 2.84 & 2.77 & 2.63 & 2.97 & 2.80 & 2.48 & 2.51 & 2.33 & 2.48 & 2.45 \\
\hline & & 3.95 & 3.87 & 3.84 & 3.85 & 3.88 & 3.67 & 3.76 & 3.67 & 3.50 & 3.65 \\
\hline & & \multicolumn{5}{|c|}{ Beautiful } & \multicolumn{5}{|c|}{ Polished } \\
\hline & $\mathrm{R}$ & 4.64 & 4.67 & 4.62 & 4.35 & 4.57 & 4.99 & 5.17 & 5.02 & 4.90 & 5.02 \\
\hline & M & 4.12 & 4.13 & 4.09 & 4.15 & 4.12 & 4.55 & 4.57 & 4.56 & 4.48 & 4.54 \\
\hline & $\mathrm{N}$ & 3.59 & 3.35 & 3.34 & 3.59 & 3.47 & 3.86 & 3.92 & 3.67 & 3.87 & 3.83 \\
\hline & S & 3.66 & 3.60 & 3.50 & 3.99 & 3.68 & 4.32 & 4.33 & 4.12 & 4.31 & 4.27 \\
\hline & Lregion & 4.00 & 3.94 & 3.89 & 4.02 & 3.96 & 4.43 & 4.50 & 4.34 & 4.39 & 4.42 \\
\hline
\end{tabular}

Table 4. - Mean scores for the four scales, split up by speaker region and listener region.

Scales range between 1 and 7. $\mathrm{R}=$ Randstad, $\mathrm{M}=$ Middle, $\mathrm{N}=$ North, $\mathrm{S}=$ South, Sregion $=$ mean score of speakers of a region over all listeners, Lregion $=$ mean score of listeners of a region over all speakers. 
There is a significant effect of speaker region for standard (see Table 3). Pairwise t-tests (with Bonferroni correction $\alpha=.05 ; \mathrm{p}<.017$ ) reveal the following order of standardness: $\mathrm{R}>\mathrm{M}>\mathrm{N}>\mathrm{S}$. The Randstad accent is considered the most standard (5.02), the South one the least standard (2.80). As confirmed by the significant interaction, the evaluation by listeners from Randstad, Middle and North is very homogeneous, whilst Southern listeners are a bit exceptional: they evaluate their own Southern accent less negative than the listeners from the other regions and they evaluate speakers from the Randstad less positive than listeners from the other regions. Nevertheless, also for listeners from South speech from the Randstad is the most standard accent in The Netherlands.

For the scale not-regional the results are very similar to those for standard. There is a significant effect of speaker region and an interaction of speaker region and listener region. The same order shows up in the pairwise t-tests: $\mathrm{R}>\mathrm{M}>\mathrm{N}>\mathrm{S}$, with speakers from the Randstad being the least regional and those from South the most regional. The evaluations by Randstad, Middle and North listeners are very similar, listeners from South show a slightly different pattern: they consider speakers from the Randstad more regional (4.58) than listeners from other regions do (scores between 5.06 and 5.20). The main effect of listener region is caused by participants from the South region: their overall evaluations are more regional (3.50) than those in the other regions (3.66-3.75).

There is a significant effect of speaker region for the scale beautiful, the pairwise t-tests distinguish three groups: $\mathrm{R}>\mathrm{M}>\mathrm{S}=\mathrm{N}$. Randstad speech is considered the most beautiful accent, speech from North and South are considered as the least beautiful accents. Once more, we observe that listeners from South are different from those of the other regions and have lower ratings for Randstad speech and higher rating for their own speech. It should be noted that this patterns is mainly present in the spontaneous speech data (see the three-way interaction and Pinget et al., 2013).

Finally, there is a significant main effect of speaker region for the scale polished. The pairwise t-test distinguishes between the four regions: $\mathrm{R}>\mathrm{M}>\mathrm{S}>\mathrm{N}$. Randstad speech is considered the most polished, speech from the North as the least polished. 


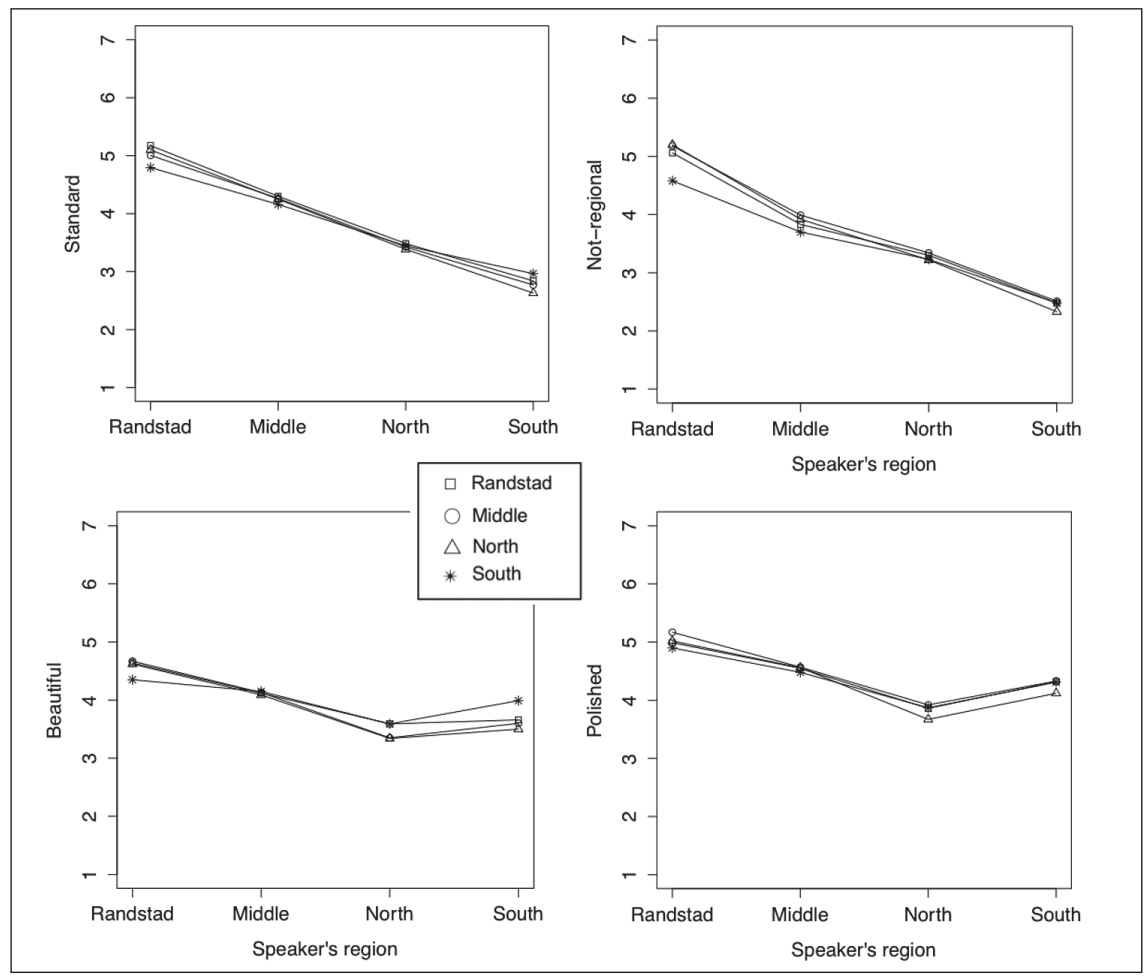

Figure 2. - The interaction of speaker region and listener region for the four scales.

The scores range between 1 (completely disagree) and 7 (completely agree). The speaker's region is on the horizontal axis, the lines represent the listener's regions.

\section{How does the number of speakers per region affect the region effects?}

We pointed already out that our results are not completely in line with those of Grondelaers et al. (2010). In a similar study of the evaluation of regional variation in standard Dutch, they found no interactions between speaker region and listener region and claim that there is a homogeneous standard pronunciation norm in The Netherlands. Why are Grondelaers et al.'s results different from ours? Their speakers were drawn from the same data set, and their spontaneous speech samples were selected according to the same criteria. The four same regions were used, for both speakers and listeners. However, there were a number of methodological differences. Grondelaers et al. (2010) had 133 listeners, our study 429. They used 18 scales that were reduced to four components in the analysis, while we 
analysed the four original scales used in our evaluation study separately. They also opted for a different statistical technique, analysis of variance, which does not model the random effects of speaker and listener as in our mixed model linear regression. Finally, they selected other (old males) and less speakers (only 2) per region. We focus on the latter difference, and investigate in our data the impact of the size of the speaker set on the significance of the effects for speaker region, listener region and their interaction, in order to get insight in the number of speakers that are needed per region to get valid results.

First we generated all possible unique combinations of two, three and four speakers per region from our original (and unique) set of five speakers per region. There are 10000 combinations of two speakers, 10000 combinations of three speakers and 625 combinations of four speakers. For all these combinations and for the four scales, we ran the same mixed model linear regression analyses as presented in Section 4, in total 82500 analyses. The number of significant effects for speaker region, listener region and the interaction between speaker region and listener region are presented in Table 5, split up by speaker set $(2,3$, and 4$)$ and evaluation scale. We also give the p-value of the analysis of the full (5) speaker set, which serves as a point of reference for the smaller data sets.

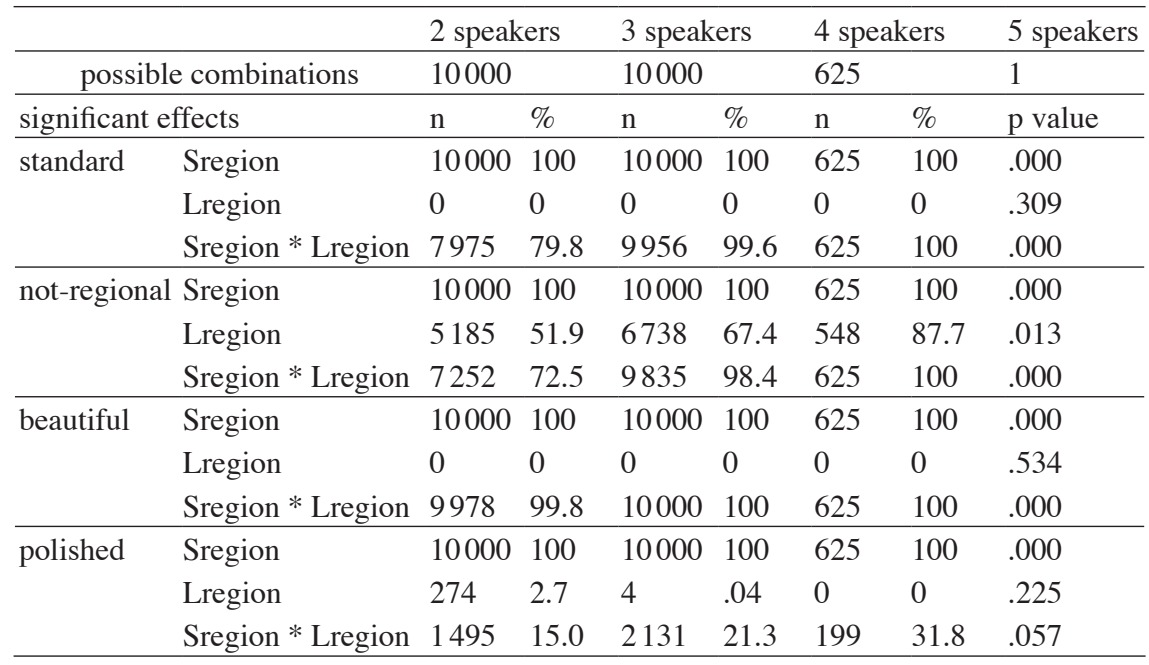

Table 5. - Overview significant region effects for speaker sets with different sizes.

The final column gives the p-values of the analysis of the full speaker set ( 5 speakers per region), which is the reference point for the analyses with smaller speaker sets. For 2, 3, and 4 speakers per region we give per scale and per factor the absolute number and percentage of analyses that show significant results $(\mathrm{p}<.05)$. Sregion $=$ speaker region, Lregion $=$ listener region. 
For the four scales there is a significant effect of speaker region in the full data set (last column of Table 5). It appears to be very stable, as it shows up in all combinations of two, three and four speakers (scores of $100 \%)$. For the interaction of speaker region and listener region, which is in the full data set significant for standard, not-regional and beautiful, and almost significant for polished $(\mathrm{p}=.057)$, the picture is more diverse. For beautiful, in $99.8 \%$ of the 2 speaker combinations the significant interaction shows up, with only $0.2 \%$ false negatives. But for the two other scales with a significant effect, the number of type II errors is much higher. $79.8 \%$ significant in two speaker combinations for standard implies that in more than $20 \%$ of the combinations there was a false negative (type II error). For not-regional significant interactions show up in $72.5 \%$ of the combinations-implying $27.5 \%$ false negatives -in the two speaker sets. Adding a third speaker gives much better results: $100 \%$ for beautiful, $99.6 \%$ for standard and $98.4 \%$ for not-regional. Combinations of four speakers for these three scales always show the significant interaction and do not show false negatives at all.

However, if an effect is close to the critical .05 value, the results on the basis of smaller speaker sets become unstable. In the case of the almost significant interaction $(\mathrm{p}=.057)$, we see that the number of false positives (type I error) is high and increases with the number of speakers in a set: $15 \%$ for sets of two, $21.3 \%$ for sets of three and $31.8 \%$ for sets of four speakers. In the case of listener region for the scale not-regional (=.013 in the full speaker set), significant effects show up in 51.9, 67.4 and $87.7 \%$ of respectively the two, three and four speaker combinations, meaning that the number of false negatives (type II error) is high in smaller speaker sets (48.1\% in two, $32.6 \%$ in three, and $12.3 \%$ in four speaker sets).

If an effect is clearly not significant on our full data set of five speakers per region, the risk for false negatives or type II errors is small. They do not show up at all for listener region for the scales beautiful $(\mathrm{p}=.534)$ and standard ( $\mathrm{p}=.309)$, and only a limited number of time for listener region for the scale polished: $2.7 \%$ in the two speaker sets and $.04 \%$ in the three speaker sets.

\section{Conclusion}

This evaluation study of standard Dutch speech - as spoken by Dutch language teachers from four different regions in The Netherlands-showed that Dutch listeners are able to distinguish these regional accents and evaluate them differently. Speech from the Randstad area, the economic and cultural centre of The Netherlands, is considered to be the most standard 
accent all over The Netherlands. As these speakers are generally recognised as speakers from that area (Pinget et al., to appear), it cannot be claimed that Randstad Dutch is Dutch without an accent. For the accent norm scales standard and not-regional, the order of the regions - in decreasing order of standardness - is Randstad $>$ Middle $>$ North $>$ South. For the accent euphony scales beautiful and polished, the picture is slightly different. Randstad always gets the highest scores, with Middle as the runner-up, but for beautiful both North and South get the lowest scores, for polished South scores significantly higher than North. However, contrary to Grondelaers et al. (2010), the evaluations were not completely homogeneous from the point of view of the regional background of the listeners. Interactions showed up between the speakers' regional accents and the listeners' regional origin. It appeared that listeners from the South valued their own accent more than listener's from other regions, and that they had less positive views of the Randstad accent. This result provides additional support for the observation that people from the South emphasize and create their regional identity by using more regional characteristics in their standard speech, partly as a reaction to the Randstad dominance (Cornips, 1994, 2012).

In an attempt to explain the differences between our study and the one by Grondelaers et al. (2010), we conducted a simulation study in which we tested how the number of speakers per region influences the statistical significance of effects in comparison with our full data set of five speakers per region. Grondelaers et al. only used two speakers per region. Our simulation showed that for this type of research on accent evaluation, two speakers per region is enough to capture the differences between the accents. However, to capture the subtle interactions between speaker region and listener region, at least three speakers per region are needed to reduce the number of false negatives (type II errors) to an acceptable level (i.e. less than 5\%). Sets of four speakers result in the same results as the full set of five speakers per region, except in cases where a significant effect is just below .05 . If the p-value is just above the critical .05 value, the risk of false positives (type I errors) is high. In other cases the risk for type I errors is very low, even with a limited number of speakers per region.

To capture subtle differences in accent evaluation, that might be an indication of changing language attitudes in process, it is clear that selecting more than the traditional one or two speakers per accent is a methodological necessity. 


\section{Acknowledgements}

The authors thank Marjolein Rotteveel, who conducted the experiment on spontaneous speech for her MA thesis, and whose results inspired us to continue this line of research. Eduard Kleerekoper developed CLEO, the application used for data collection, thanks to a grant from the Faculty of Humanities of Utrecht University. We thank Roel Willems, Hugo Quené, Mattis van den Berg and Roeland van Hout for statistical advice. The speech data were collected with a grant from the Flemish and Dutch Scientific Organizations.

\section{REFERENCES}

Adank Patti, van Hout Roeland, and Van de Velde Hans, 2007, “An Acoustic Description of the Vowels of Northern and Southern Standard Dutch II: Regional Varieties", Journal of the Acoustical Society of America, 121, pp. 1130-41.

Cornips Leonie, 1994, Syntactische variatie in het Algemeen Nederlands van Heerlen, Amsterdam, IFOTT.

Cornips Leonie, 2012, Talen in beweging, Maastricht University.

Grondelaers Stefan A., van Hout Roeland, and Steegs Mieke, 2010, "Evaluating Regional Accent Variation in Standard Dutch", Journal of Language and Social Psychology, 29 (1), pp. 101-16.

Hoppenbrouwers Cornelis and Hoppenbrouwers Geer, 2001, De indeling van de Nederlandse streektalen. Dialecten van 156 steden en dorpen geklasseerd volgens de FFM, Assen, Koninklijke Van Gorcum.

KRAAYKAMP Gerbert, 2005, "Dialect en sociale ongelijkheid. Een empirische studie naar de sociaal-economische gevolgen van het spreken van dialect in de jeugd", Pedagogische Studiën, 82, pp. 390-403.

Kissine Mikhail, Van de Velde Hans, and van Hout Roeland, 2003, “The Devoicing of Fricatives in Standard Dutch", in P. Fikkert and L. Cornips (eds), Linguistics in The Netherlands 2003, Amsterdam, John Benjamins, pp. 93-104.

Pinget Anne-France, Rotteveel Marjolein, and Van de Velde Hans, (to appear), Standaardnederlands met een accent: herkenning en evaluatie van regionaal gekleurd Standaardnederlands in Nederland, Nederlandse Taalkunde.

Smakman Dick, 2006, Standard Dutch in The Netherlands. A Sociolinguistic and Phonetic Description, Utrecht, Landelijke Onderzoekschool Taalwetenschap.

Van de Velde Hans and Houtermans Muriël, 1999, "Vlamingen en Nederlanders over de uitspraak van nieuwslezers", in E. Huls and B. Weltens, Artikelen van de Derde Sociolinguïstische Conferentie, Delft, Uitgeverij Eburon, pp. 451-62.

Van de Velde Hans, Kissine Mikhail, Tops Evie, van der Harst Sander, and van Hout Roeland, 2010, "Will Dutch Become Flemish? Autonomous Developments in Belgian Dutch", Multilingua, 29 (3/4), pp. 385-416.

VAn de Velde Hans and van Hout Roeland, 2002, "Loan Words as Markers of Differentiation", in H. Broekhuis and P. Fikkert (eds), Linguistics in The Netherlands 2002, Amsterdam, John Benjamins, pp. 163-73. 
Van de Velde Hans, van Hout R., and GerRitsen Marinel, 1997, "Watching Dutch Change: A Real Time Study of Variation and Change in Standard Dutch Pronunciation", Journal of Sociolinguistics, 1, pp. 361-91.

VAn Der Harst Sander, 2011, The Vowel Space Paradox, Utrecht, Landelijke Onderzoekschool Taalwetenschap.

Van der Harst Sander, Van de Velde Hans, and Schouten M.E. H., 2007, "Acoustic Characteristics of Standard Dutch /y/", in Proceedings of the 16th International Congress of Phonetic Sciences, pp. 1469-72.

Van der Harst Sander, Van de Velde Hans, and van Hout Roeland, (to appear), "Variation in Standard Dutch Vowels: The Impact of Formant Measurement Methods on Identifying the Speaker's Regional Origin", Language Variation and Change.

Van Haeringen C. B., 1924, "Eenheid en nuance in beschaafd-Nederlandse uitspraak", De Nieuwe Taalgids, 18, pp. 65-86.

Van Haeringen C. B., 1951, "Standaard Nederlands", De Nieuwe Taalgids, 44, pp. 316-20.

Van Hout Roeland, De Schutter Georges, De Crom Erika, Huinck Wendy, Kloots Hanne, and VAN De Velde Hans, 1999, "De uitspraak van het Standaard-Nederlands: variatie en varianten in Vlaanderen en Nederland", in E. Huls and B. Weltens (red.), Artikelen van de Derde Sociolinguïstische Conferentie, Delft, Uitgeverij Eburon, pp. 183-96.

Verstraeten Bart and Van de Velde Hans, 2001, "Socio-Geographical Variation of $/ \mathrm{r}$ / in Dutch", in H. Van de Velde and R. van Hout (eds), 'r-atics: Sociolinguistic, Phonetic and Phonological Characteristics of $/ r /$, Special issue of Études \& Travaux, 4, pp. 45-61. 